\title{
The role of Typha sp. in affecting the radium behavior in the water column of a salt coastal lagoon
}

\author{
D.C. Lauria ${ }^{1,2}$ and J.M. Godoy ${ }^{1,2}$
}

\author{
${ }^{1}$ Instituto de Radioproteçao e Dosimetria, Departamento de Radioproteçao Ambiental, \\ CEP 22780-160 Rio de Janeiro, Brazil \\ ${ }^{2}$ Departamento de Quimica, Pontificia Universidade Catolica do Rio de Janeiro, \\ rua Marquês de Sao Vicente 225, Gavea, CEP 22453-00 Rio de Janeiro, Brazil
}

\begin{abstract}
The radium accumulation and releasing in Typha Domingenes Pers. foliage in a coastal lagoon was studied by in situ and lab experiments. From leaf sample analysis and lab experiments, adsorption experiments followed by procedure sequential extraction, it was observed the importance of the ionic exchange for the foliar accumulation. The higher the salinity, the lower the accumulation in leaves. Decomposition of leaves was studied by litterbag methods during a period of 6 months. At the end of the experiments the major cation losses were $99 \%$ of $\mathrm{K}, 76 \%$ of $\mathrm{Na}$ and $51 \%$ of $\mathrm{Mg}$. On the other hand the amount of $\mathrm{Ca}$ in the residue increased seven times as well as increased the total activity of ${ }^{226} \mathrm{Ra}$ and of ${ }^{228} \mathrm{Ra}$ (seven and at least three times, respectively). In agreement with this observation, laboratory experiments showed that the material was able to adsorb quite a $100 \%$ of the added $\mathrm{Ra}$ and its adsorption capacity was estimated at $5 \mathrm{meq}\left(\mathrm{Ba}^{2+}\right) / \mathrm{g}_{\text {detritu. }}$. Radionuclide releasing by sequential extraction of the detritus material followed a little bit different dynamic from the green leaves, showing that important fraction of the radium can be retained in the litter by humidified material.
\end{abstract}

\section{INTRODUCTION}

The Buena lagoon is a shallow salt lagoon whose water column contains abnormal high concentrations of radium isotopes. The Ra-226 concentration ranges from 0.05 to $0.89 \mathrm{~Bq} / \mathrm{L}$, while the $\mathrm{Ra}-228$ concentration ranges from 0.07 to $2.01 \mathrm{~Bq} / \mathrm{L}$. The salinity varies between 9 and $42 \%$ and the $\mathrm{pH}$ between 4.2 and 7.3. The radionuclide concentrations decrease in seawater direction, while the $\mathrm{pH}$ and its salinity increases in the same direction [1]. The lagoon and its wetland are largely covered by aquatic vegetation, mainly Typha Domingensis Pers. Typha sp. (cattails) is a rooted aquatic macrophyte plant, commonly found in tropical and temperate wetlands, whose behaviour has been studied with the aim to use it in polluted systems and for energy production $[2,3,4]$.

Rooted macrophyte plants can accumulated minerals from water column and sediment, being the free accessibility of water and solutes an important factor for foliage uptake to cell wall. However, there is not a consensus yet on which is the main route for nutrients uptake by plant, if foliar or root uptake [5, 6]. From literature data gathering the average value of concentration ratio, $C R$, for radium from water to plant wet foliage was estimated at 55 [7]. Iyengar and Rao reported values of radium CR for different rooted macrophytes ranging from 30 to 1400 , being the recommended value 100 , while the CR from sediment to wet aquatic plant foliage was estimated at 0.014 , independently of the water contribution [8].

Plant decomposition is a process that involves physical, chemical and biological events resulting in the production of $\mathrm{CO}_{2}$, minerals (as example calcite: $\mathrm{CaCO}_{3}$ ), water and humified organic matter. Basically, the decomposition occurs in three steps. The first step of process involves physical leaching of nutrients and dissolved organic compounds (soluble carbohydrates, lipids and polyphenols), which account for 6 to $40 \%$ dry weight loss within 15 days. The leaching phase is followed by microbial decomposition by bacteria and fungi, leading to decomposition of structural compounds such as cellulose, hemicelluloses and lignin. Then, a third step characterized by the reduction of bacterial activity takes place until the decomposition stops, remaining the refractory foliage material $[9,10,11]$.

Typha domingensis Pers. is the unique Typha sp. specie found in Brazil, it can be found in most wetlands and coastal lagoons. Its foliage is responsible for 60 to $70 \%$ of the whole plant biomass and for the larger nutrient deposit of the plant [2]. Its organic matter content is higher than $85 \%$ and the wall cell comprises around $70 \%$ of the foliage [12]. The foliage is composed by circa of $20 \%$ of polyphenols and $40 \%$ of soluble carbohydrates [13]. Furtado, comparing the constituents in green leaves and in leaf detritus observed that the detritus presents $31 \%$ less of organic matter, $50 \%$ less of cell wall, $62 \%$ less of soluble carbohydrate, $21 \%$ less of lipids and $80 \%$ less of the tannin than the green leaves [12]. After six month of Typha foliage decomposition experiment, Couto observed a loss of 40 to $80 \%$ of potassium, 40 to $90 \%$ of sodium, 60 to $80 \%$ of magnesium, $40 \%$ of calcium and iron and 40 to $60 \%$ of manganese [14].

The evaluation of the role of Typha in the Buena lagoon system is important to assess the radium cycling and its reflection on the observed high radium concentration on lagoon water column. On the 
other hand, the obtained information can be useful regarding the understanding of radium behaviour in natural aquatic systems as well as the use of Typha sp. for recovering radium from aqueous effluents of uranium mining and milling. The aiming of this research was to study the role of Typha sp. in the cycling of radium in the lagoon considering its utilization for remediation of mine drainage wastes.

\subsection{Material and Methods}

\subsubsection{The study area}

The Buena Lagoon belongs to the São Francisco de Itabapoana county in the Rio de Janeiro State, Brazil, between the coordinates $21^{\circ} 23^{\prime}-21^{\circ} 24^{\prime} \mathrm{S}$ and $41^{\circ} 00^{\prime}-41^{\circ} 03^{\prime} \mathrm{W}$. Its watercourse surface area is 0.11 $\mathrm{km}^{2}\left(113,000 \mathrm{~m}^{2}\right)$, whose length is $5.4 \mathrm{~km}$ and the average width is $21 \mathrm{~m}$. Its wetland has an area of $670,000 \mathrm{~m}^{2}$, being $518000 \mathrm{~m}^{2}$ completely covered by Typha Domingensis Pers., and its catchments area comprises $7.5 \mathrm{~km}^{2}$. The lagoon is shallow (maximum depth $3 \mathrm{~m}$ ) and it is separated from the ocean bya barrier of sand, which width is approximately 15 meters and eventually, direct seawater inflow can occur.

\subsubsection{Sampling and Chemical Analysis}

The lagoon map was digitalized and information about size, width, catchments and wetland areas wert obtained by IDRISIS software. Neither sampling station 1 nor sampling station 7 were found cattails, showing that due to their characteristic water, at station 1, low pH 4, (at the lagoon head) and at station? (located close to sea) high salinity $42 \%$, the plant growing was not possible. At the other stations, plant population was determined by counting the number of plants per square meters. A $1 \mathrm{mx} 1 \mathrm{~m}$ square was randomly placed at five points in each sampling point. All the cattails within the square were counted. From one of square the total leaves were sampled. These samples were collected in two periods: one of dry and the other of rain seasons. At the laboratory the samples were cleaned with distilled water, airdried, weighted and dried in a forced air oven at $80^{\circ} \mathrm{C}$. After that the samples were burnt at $450^{\circ} \mathrm{C}$ and 10 $\mathrm{g}$ of ashes were digested with $3: 1$ mixture of nitric and chloride acid. ${ }^{228} \mathrm{Ra}$ and ${ }^{226} \mathrm{Ra}$ were analysed by total alpha and beta counting [15]. The accuracy of such determination is routinely tested by interlaboratory exercises organized by the EPA/USA and the Radionuclide Metrology Division of IRD/CNEN [16].

Sediment and water samples were collected from the same points of cattail sampling. The sediment was collected with an auger to a depth of $10 \mathrm{~cm}$ and transferred to plastic bags. Immediately after the sampling, sediment $\mathrm{pH}$ and Eh measurements were performed in the wet sediment. At the lab the sediments were air dried and passed through a $2 \mathrm{~mm}$ sieve. After 20 days, the samples were analysed by gamma spectrometry Ra-226 (Pb-214, $614 \mathrm{keV}$ ) and Ra-228 (Ac-288, $911 \mathrm{keV})$.

About $3.0 \mathrm{~L}$ of water in a polyethylene bottle were collected at each sampling point, in two different seasons - a rainy and a dry. Eh, $\mathrm{pH}$ and conductivity were measured directly at the site. A Millipore membrane filtered the water and the sample was acidified with nitric acid supra pure for the determination of the radionuclides and cations. Major cations were analysed by inductively coupled plasma-mass spectrometry, ICP-MS, Perkin-Elmer ELAN 5000, after a dilution 1:1000 with water, Milli$\mathrm{Q}$, applying the so-called "TotalQuant" method and In and Tl as internal standards. A total of 27 elements were used for the equipment mass efficiency calibration. Using 1-liter sample, ${ }^{228} \mathrm{Ra}$ and ${ }^{226} \mathrm{Ra}$ were analysed by total alpha and beta counting [15].

\subsubsection{In situ decomposition}

The Typha leaves were cut into $15 \mathrm{~cm}$ segments and oven dried at $80^{\circ} \mathrm{C}$ to constant weight and $10 \mathrm{~g}$ of dry leaves were placed in nylon litter bags (1mm mesh size). Forty $20 \times 15 \mathrm{~cm}$ size bags were taken in total. The bags were placed on the bottom of the lagoon, submerged under $30-50 \mathrm{~cm}$ water, at sampling station 5. Five bags were taken out at different intervals of time and then they were washed in lagoo: water and rinsed in distilled water. The plant material was dried in hot air oven at $80^{\circ} \mathrm{C}$, weighed, and powdered in quartz mortar for chemical analysis of $\mathrm{Na}, \mathrm{K}, \mathrm{Ca}, \mathrm{Mg}, \mathrm{Ra}-228$ and $\mathrm{Ra}-226$. The radium concentration in the six months material could not be determined, due to the small quantity of recoverd material.

\subsubsection{Laboratory adsorption experiments}

Green leaves: $15 \mathrm{~g}$ of green leaves in pieces of $10 \mathrm{~cm}$ were placed in $250 \mathrm{ml}$ Teflon centrifuge tube and immersed in $50 \mathrm{ml}$ of a solution, $\mathrm{pH} 6$, containing $32 \mathrm{~Bq}$ of $\mathrm{Ra}-228$ and $1 \mathrm{~g} / \mathrm{L} \mathrm{NaCl}$, for 8 days. Then the 
leaves were taken out of solution, washed with distilled water, fractionated into little pieces and placed in polyetbylene bottles for counting on a germanium detector.

Detritus: the six-month foliage detritus were ground in a quartz mortar to pass a $2 \mathrm{~mm}$ screen. Then, $0.05 \mathrm{~g}$ of the samples was placed in a Teflon tube and $50 \mathrm{ml}$ of lagoon water and $12 \mathrm{~Bq}$ of Ra-228 were added to the detritus. After 24 hours the detritus was filtered in a Millipore membrane $5 \mathrm{~cm}$ diameter, $0.45 \mu \mathrm{m}$. The filter was washed with distilled water and analysed by a germanium detector.

The adsorption capacity of the detritus was evaluated by adding $0.05 \mathrm{~g}$ of the detritus material to $50 \mathrm{ml}$ solution, $\mathrm{pH}=6.8$, containing $60 \mathrm{mg}$ of $\mathrm{Ba}^{++}$and $23 \mathrm{~Bq}$ of $\mathrm{Ba}-133$. The sample was allowed to stand for 24 hours before filtering in a Millipore membrane $5 \mathrm{~cm}$ diameter, $0.45 \mu \mathrm{m}$. The filter supporting the detritus was washed with distilled water and analysed on a germanium detector

\section{RESULTS}

The radium concentration in foliage was inversely correlated with the logarithm of addition of $\mathrm{Ca}$ and $\mathrm{Mg}$ concentrations in the water $(\mathrm{r}=0.73$ for $\mathrm{Ra}-226$ and 0.55 for $\mathrm{Ra}-228, \mathrm{P}<0.01)$, table 1 , supporting the hypotheses that $\mathrm{Ra}$ was accumulated and distributed within the plant by the same mechanisms as the divalent cations and that a probable competition among the cations for adsorption sites in the plant is occurring [7]. It was not observed correlation between the $\mathrm{pH}$ in the water or in sediment with the radium concentration in foliage.

Amounts of metals removed from water by cattail depend upon cattail biomass and concentration of metals in plants. Foliage biomass ranged from 230 to $1180 \mathrm{~g}$ dry matter. $\mathrm{m}^{-2}$. As it was not found statistical significant difference of the plant biomass between the sampling seasons and among the sampling stations, the average biomass could be estimated as $610 \mathrm{~g}$ dry matter. $\mathrm{m}^{-2}$. The values of biomass fall into the observed range for Typha in other Brazilian coastal lagoons (105 to $1600 \mathrm{~g}$ dry matter.m $\mathrm{m}^{-2}$ ) $[13,14]$. The relationship between wet to dry mass and wet to ash mass point out to $72 \%$ of water and $2.3 \%$ of ash in the foliage. Between the sampling station 2 and the sampling station 5 , the wetland area is approximately $518,000 \mathrm{~m}^{2}$, resulting in a foliage total dry mass of 316 ton (wet mass 1129 ton and ash mass 24 ton) in the lagoon. The Ra concentration in the foliage was correlated with the Ra concentration in the water column Ra-228 ( $\mathrm{r}=0.541, \mathrm{P}<0.05)$ and $\mathrm{Ra}-226(\mathrm{r}=0.499, \mathrm{P}<0.05)$. However no correlation was found among the Radium concentration in sediment and in foliage. As it is expected, no statistic difference was found between the concentration ratios CR from water to plant wet foliage of the two isotopes. The concentration ratio CR ranged from 6 to 125 and the geometric average value was estimated as 33. This CR average value is lower than that one observed in rooted macrophyte, showing that Typha in that lagoon system is not specially a good radium accumulator.

By testing the difference among geometric average (two tailed t-test) and comparison of geometric standard deviations (F-test), the station 2 was identified as the station of more elevated concentration of radium isotopes. As it was not found significant statistically difference among the radium concentration in the other stations, the geometric average concentrations of Ra-226 and Ra-228 in wet foliage was determined for station 2: 11.7 and $21 \mathrm{~Bq} / \mathrm{kg}$ respectively, while for the other stations $(3,4$ and 5): 5.3 $\mathrm{Bq} / \mathrm{kg}$ for Ra-226 and $7.3 \mathrm{~Bq} / \mathrm{kg}$ for Ra-228. In the gross, it is possible to estimate the total activity of radium in the cattail foliage. By IDRISIS software, the wetland area at station 2 was estimated as app. $64,000 \mathrm{~m}^{2}$, corresponding to a wet foliage mass of 139 ton and $2 \mathrm{MBq}$ of Ra-226 and $3 \mathrm{MBq}$ of Ra-228. The other 990 ton of foliage would contain $5 \mathrm{MBq}$ of Ra-226 and $7 \mathrm{MBq}$ of Ra-228, bringing up a total of $7 \mathrm{MBq}$ of Ra-226 and $10 \mathrm{MBq}$ of Ra-228 in 300 ton of dry foliage (24 tons of ashes). As the activity of radium isotopes in water column of Buena lagoon were estimated as $20 \mathrm{MBq}$ of Ra-226 and $40 \mathrm{MBq}$ of Ra-228 [1], the foliage would contain app. $20 \%$ of total radium of the system water-foliage. But in the case of foliage cutting aiming decontamination, it is interesting to notice that this amount of radium isotopes would be contained in a waste of 24 -ton ashes. 
Table 1. Concentration values of $\mathrm{Ra}-226, \mathrm{Ra}-228$ and magnesium plus calcium in the different compartments of the lagoon,

\begin{tabular}{|c|c|c|c|c|c|c|c|c|c|c|}
\hline \multirow{2}{*}{$\begin{array}{l}\text { Sampling } \\
\text { Station }\end{array}$} & \multicolumn{2}{|c|}{ Foliage } & Biomass & \multicolumn{2}{|c|}{ Sediment } & \multirow[b]{2}{*}{$\begin{array}{c}\mathrm{Ra}-226 \\
\mathrm{~Bq} / \mathrm{L}\end{array}$} & \multicolumn{4}{|c|}{ Water } \\
\hline & $\begin{array}{r}\mathrm{Ra}-226 \\
\mathrm{~Bq} / \mathrm{l}\end{array}$ & $\begin{array}{l}\mathrm{Ra}-228 \\
\mathrm{fresh}\end{array}$ & $\mathrm{g}_{\mathrm{dry}} \cdot \mathrm{m}^{-2}$ & $\begin{array}{r}\mathrm{Ra}-226 \\
\mathrm{~B}\end{array}$ & $\begin{array}{l}\mathrm{Ra}-228 \\
\mathrm{~d} / \mathrm{kg}\end{array}$ & & $\begin{array}{r}\mathrm{Ra}-228 \\
\mathrm{~Bq} / \mathrm{L}\end{array}$ & $\begin{array}{r}\mathrm{Mg}+\mathrm{Ca} \\
\mathrm{mg} / \mathrm{L}\end{array}$ & $\mathrm{pH}$ & $\begin{array}{c}\text { Cond. } \\
\mathrm{ms}\end{array}$ \\
\hline 2 & 3.9 & 20 & 340 & 14 & 43 & 0.23 & 0.93 & 333 & 6.1 & 10.0 \\
\hline 2 & 17 & 28 & 530 & 34 & 94 & 0.28 & 0.81 & 51 & 6.1 & 2.8 \\
\hline 2 & 21 & 31 & 660 & 39 & 82 & 0.28 & 0.66 & 63 & n.a & 3.5 \\
\hline 2 & 14 & 11 & 630 & 28 & 90 & 0.25 & 0.56 & 49 & 5.9 & 2.5 \\
\hline 3 & 1.3 & 3.7 & 580 & 34 & 89 & 0.20 & 0.36 & 100 & 6.6 & 5.4 \\
\hline 3 & 9 & 12 & 420 & 30 & 79 & 0.23 & 0.50 & 66 & 6.2 & $\overline{4.3}$ \\
\hline 3 & 15 & 7.4 & 300 & 36 & 80 & 0.18 & 0.46 & 90 & n.a. & 4.6 \\
\hline 3 & 4.2 & 4.6 & 740 & 31 & 76 & na & na & 162 & 4.4 & 6.9 \\
\hline 4 & 4.6 & 15 & 450 & 180 & 233 & 0.21 & 0.30 & 115 & 6.7 & 5.7 \\
\hline 4 & 12 & 30 & 230 & 113 & 491 & 0.17 & 0.22 & 82 & 6.2 & 3.8 \\
\hline 4 & 8.2 & 3.5 & 760 & 75 & 301 & 0.14 & 0.31 & 107 & n.a. & 5.3 \\
\hline 4 & 0.61 & 2.8 & 1180 & 83 & 350 & 0.12 & 0.15 & 107 & 6.4 & 3.0 \\
\hline 5 & 10 & 17 & 540 & na & na & 0.21 & 0.39 & 135 & 6.8 & 5.2 \\
\hline 5 & 13 & 3.8 & 970 & na & na & 0.11 & 0.19 & 178 & 6.4 & 6.3 \\
\hline 5 & 3.2 & 7.9 & 670 & na & na & 0.08 & 0.08 & 101 & n.a. & 3.9 \\
\hline
\end{tabular}

n.a. Not analysed.

\subsection{In situ decomposition}

The data from detritus decomposition show that $65 \%$ of dry weight was lost within 6 months. The value of decomposition rate calculated by the decay exponential function [10] was high, $0.0072 \mathrm{~d}^{-1}$, which means that the remaining material after one year would be equal to $7 \%$ of the initial material.

During decomposition potassium was lost quickly, $98 \%$ of the total content during the first 15 days. The changes in $\mathrm{Na}$ and $\mathrm{Mg}$ followed a similar pattern, losing ca. $50 \%$ of their initial amount during the first step of decomposition, after that the loss was quite slower. About $20 \%$ of sodium and magnesium was still left after 6 months
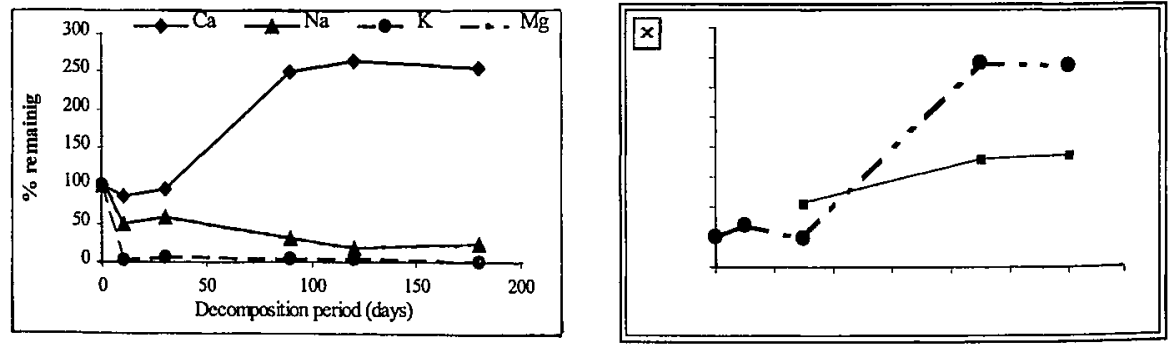

Figures 1 and 2: Changes in $\mathrm{K}, \mathrm{Na}, \mathrm{Mg}, \mathrm{Ca}$ and $\mathrm{Ra}$ content of decomposition plant material.

Completely different was the calcium behaviour during the decomposition. The calcium content remained almost constant during the first month; after that, increased reaching values 2.6 times more elevated that the initial one (figure 1). The behaviour of radium was quite similar to the calcium one (figure 2) and a significant correlation were found between their contents in detritus $(r=0.89, \mathrm{P}=0.05)$, suggesting similar processes to both cations sorption.

According to the decomposition phases, the quick loss of $\mathrm{K}, \mathrm{Na}$ and $\mathrm{Mg}$ in the beginning is related to the leaching of these nutrients, which are weakly binding to the plant tissue. The calcium and radium behaviour during the first 30 days could be justified by its accumulation as insoluble deposits in plants [7], remaining incorporated to the material. After that, however, their content increasing could be attributed either to contamination by silt or molluscs or to their sorption on detritus sites. In this case, decomposition of structural compounds by microbial process, which would breakdown large moleculesin smaller ones, would expose smaller molecules with higher sorption capacity than the original one. 


\section{Laboratory adsorption experiments}

The adsorption experiments showed that $69 \%(22 \mathrm{~Bq})$ of initial radium was retained on the green leaves, pointing out to a passive process of adsorption on cell walls.

The sorption of radium by detritus was almost $100 \%$ of the added radium $(11.9 \mathrm{~Bq})$, showing that the detritus can really adsorb radium and that the observed increase of the radium and calcium concentrations in decomposition field experiment could be attributed to sorption process, instead of contamination. The sorption capacity experiment resulted in sorption of $28 \%$ of Ba-133, corresponding to $17 \mathrm{mg} \mathrm{de} \mathrm{Ba}^{++}$ accumulated on $0.05 \mathrm{~g}$ of detritus, meaning a sorption capacity of $340 \mathrm{mg}$ of Ba/g $/ \mathrm{g}_{\text {deritus. }}$.

The contaminated detritus and green leaf were exposed to $0.01 \mathrm{~N}$ of ethylenediaminetetraacetic acid (EDTA) solution during 1 minute, and then the solution was analysed by gamma spectrometry. The activity concentration in the solution was less than minimum detectable concentration, pointing out to less than $6 \%$ of the radium and barium accumulated by the materials could be recovered by EDTA, so the radium binding with the material are not so weak as observed in algae foliage whose experiment of chemical desorption with EDTA resulted in a high recovery of radium [5]. Then a methodology frequently used to sediments was applied, taking into account that the chemical behaviour and ion competitions should be similar in both cases. So, the plant materials were submitted to a sequential extraction procedure using $\mathrm{MgCl}_{2}$ solution, $1 \mathrm{M}, \mathrm{pH} 7$, which due to its chemical similarity and high cation concentration can compete with radium for the exchange sites on material. Extraction with $0.6 \mathrm{M}$ $\mathrm{HOAc} / 1 \mathrm{M} \mathrm{NaOAc}(\mathrm{pH}=5)$, which could release radium from adsorption sites, specific adsorption, and radium taking part in carbonate compounds and oxidation of organic matter with $30 \% \mathrm{H}_{2} \mathrm{O}_{2}-0.02 \mathrm{M}$ $\mathrm{HNO}_{3}, 80^{\circ} \mathrm{C}$, to release that radium strongly bound to organic fraction and sulphite [17].

Approximately $60 \%$ of radium were recovered by magnesium chloride and acetic acid leaching, pointing out the importance of ionic exchange to the radium adsorption on both materials and denoting that adsorbed radium from detritus and foliage can be released to water column in case sea water inflows in the lagoon or during a dry weather long period, increasing the lagoon water ionic strength. It is interesting to notice that even though oxidation of organic matter was performed around $20 \%$ of radium remained firmly bound on the green foliage fibbers and therefore would not be released under natural conditions. Only at the end of leaf decomposition this fraction could return to the water column, unless radium is associated with refractory plant material buried in the sediment [4].

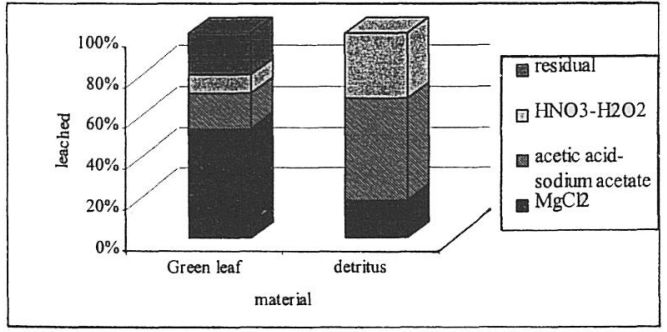

Figure 3: Radium speciation in plant materials

\section{CONCLUSION}

Typha foliage can adsorb radium by passive binding to cell walls. The accumulation by foliage is a dynamic process since a significant fraction can be released by increasing water salinity. However, a radium fraction will be so firmly bound to the plant tissue that it will hardly be released from foliage, no matter the changes in water conditions. Detritus can efficiently adsorb radium; however, as for green leaves, changing in the

water conditions could also promote the return of radium to water. Joining to sediment, the detritus will increase the sediment sorption capacity. It is possible that radium remains fixed to the humified material joined to sediment for a period of time, but at the end of the organic matter decomposition it could return to water column, then the detritus serves at least as a temporary storage compartment. The use of Typha foliage for radium remediation of water and mine effluents is depreciated by the amount of generated waste. Nevertheless, Typha detritus traps radium from aqueous solutions efficiently and its utilization for mine drainage waste remediation should be investigated. 


\section{Acknowledgments}

The authors are grateful to the technical staff of Environmental Analysis Division from DEPRA/RD, who carried out most of radiometric and radiochemical analysis.

\section{References}

[1] Lauria D.C. and Godoy J.M., Journal of Environmental Radioactivity, accepted for publication.

[2] Garver E.G., Dubbe D.R. and Pratt D.C., Aquatic Botany 32 (1988) 115-127.

[3] Dunbanbin J.S., Pokorny J., Bowmer K.H, Aquatic Botany 29 (1988) 303-317.

[4] Dunbanbin J.S., Bowmer K.H., The Science of Total Environment 11 (1992) 151-168.

[5] Kalin M. and Sharma H.D., (In International Atomic Energy Agency Technical Document (IAEA. SM-275/10,1981)) pp. 247-262.

[6]. L.J.Jackson, The Science of Total Environment (1998) 219- 223.

[7] Williams A.R. , (Technical Report Series 310, International Atomic Energy, Vienna, Vol.1, 1990) pp.487-508.

[8] Iyengar M.A.R. and Rao K.N., (The Environmental Behaviour of Radium, Technical Report Series 310, International Atomic Energy, Vienna, Vol.1, 1990) pp.59-128.

[9] Shama K.P. and Gopal B., (Wetland Ecology and Management, National Institute of Ecology and International Scientific Public, 1982) pp. 321-334.

[10] Kulshreshtha M. and Gopal B., (Wetland Ecology and Management, National Institute of Ecology: and International Scientific Public, 1982) pp. 279-292.

[11] Howard-Williams C. and Howard-Williams W., Aquatic Botany 4 (1978) 257-267.

[12] Furtado A., (Master Thesis Degree, Departamento de Ecologia, UFRJ, Rio de Janeiro, 1992) 106p.

[13] Júnior M.N.A., (Master Thesis Degree, Departamento de Geoquímica, UFF, Rio de Janeiro, 199i] $106 \mathrm{p}$.

[14] Couto E.C.G., (Master Thesis Degree, Departamento de Geoquímica, UFF, Rio de Janeiro, 1989] $242 p$.

[15] Godoy J.M., D.C. Lauria, M.L.D.P. Godoy, R.P. Cunha, R.P., Journal of Radioanalytical and Nuclear Chemistry Articles, 1821 (1994), 165-171.

[16] Vianna M.E.C.M., Tauata L., Oliveira A.E., Oliveira J.P., Clain A.F. and Ferreira A.C.M. Appl.Radiat.Isto. 49 (1998) 1463-1466.

[17] W.Salomons, U.Förtner, in Metals in Hydrocycle, Springer-Verlag, Berlin, 332 (1984). 